\title{
Ibn Ḥazm's and al-Ghazzālī's Most Divergent Responses to Christianity: A Question of Epistemology and Hermeneutics ${ }^{1}$
}

\author{
Tamara Albertini
}

Muslims consider themselves the heirs of both Judaism and Christianity. However, the Islamic religion takes the Qur'ān to be a more faithful expression of divine revelation than the Torah or the Gospels, and therefore often 'corrects' biblical narratives. This has to do with the Islamic doctrine of tậīf, which states that Jews and Christians have either distorted the 'wording' (tahrif al-nașs ) or the 'meaning' (tahrîfal-ma'ānì) of their respective sacred texts. The following Qurānic versions of some biblical stories are representative samples of the various types of 'discrepancies:'2

- Hawwa' (Eve) was not created from Adam's rib (this version only appears in the Hadith, Islam's second scriptural text). Also, she is not responsible for the Fall. Adam and Eve both disobeyed God and, accordingly, were punished equally. ${ }^{3}$

- Contextual clues in the Qur'ānic narrative suggest that Ismāîll (i.e., Ishmael, the ancestor of the Arabs through Hagar)—not Ishāq (Isaac)—was meant to be sacrificed (Q XXXVII, 102-105).

1 There is an earlier study of these two Muslim philosopher-theologians by Roger Arnaldez, "Controverses théologiques chez Ibn Hazm de Cordoue et Ghazali," Les Mardis de Dār el-Salām, Sommaire MCMLIII: 209-248. Arnaldez's study is very rich in information. It is, however, of a more descriptive nature and, accordingly, contributes little to the comparative approach taken in the present essay.

2 On 'Biblicizing' (the Qurānic narrative) and 'Islamicizing' (the Bible) as means for Islam's double appropriation of the biblical tradition, see Sidney H. Griffith, "Arguing from Scripture: The Bible in the Christian/Muslim Encounter in the Middle Ages," in Scripture and Pluralism. Reading the Bible in the Religiously Plural Worlds of the Middle Ages and the Renaissance, ed. Thomas J. Heffernan and Thomas E. Burman (Leiden: Brill, 2005), 29-58.

3 For the many relevant passages on Adam and Eve in the Qur'ān, see the section on "Anthropology" in Tamara Albertini, "Islamic Philosophy: An Overview," in The Companion to World Philosophies, ed. Eliot Deutsch and Ron Bontekoe (Oxford: Blackwell Publishers, 1997), 99-133, at 106-107. 
- King Suleymān (Solomon) is a Muslim, and Bilqīs (as the Queen of Sheba is known to Muslims) converts to Islam after meeting him (Q XXVII, 22-44).

- Maryam (Mary) grows up in the Temple where she is placed in the care of Zakariyyā (Zacharias) and receives religious education (Q III, 35-37). As in the Gospel she is a virgin-mother, but she has no male companion (i.e., no Joseph) and thus raises her son 'Īsā (Jesus) all by herself. As a result, she comes across as a much more independent figure than in Christianity.

- 'Isā is not the son of God, but just the son of Mary. Accordingly, his genealogy is reflected in his name, 'Tsā ibn Maryam, which may explain why Mary is the only woman in the Qur'ân to be called by name (for the identification of other female biblical figures one needs to rely on contextual clues). Therefore, Jesus cannot be one with God, which is why there may be no theological basis for the Christian doctrine of Holy Trinity in Islam. Muslims address Jesus as 'Sayyiduna 'İsă' (Our Lord Jesus) or 'al-Masịh' (The Messiah).

- As the Qurānic chapter named after Maryam states, Jesus performs his first miracle as a newborn by making a palm tree grow dates to help sustain his mother (Q XIX, 24-26). He also defends her against accusations of unchastity (Q XIX, 30-33).

- Finally, Jesus does not die on the cross (Q IV, 157). According to Islamic teaching, God would never submit one of his prophets to such humiliation and pain.

Clearly, the Qurannic narrative is not entirely compatible with the canonical books of the Bible. One should keep in mind, however, that the ancient Christian communities in Muslim lands happened to represent a great variety of Christological views and did not even agree on which books were canonical. Nevertheless, there is still sufficient overlap between the Muslim and Christian records to grant Mary and Jesus, for instance, a prominent place in Islam's sacred history. Many Muslim theologians go as far as to assign Jesus a major role on the Day of Judgment, a role second only to Prophet Muhammad. For this purpose, they rely on a hadīth (narration) preserved solely by Abū Hurayra, a close companion of the Prophet. Abu Hurayra, being the transmitter of over 5300 ahadith (pl. of hadith), was deemed a reliable source. Nevertheless, considering the extremely narrow textual basis, acceptance of the hadith in question by some leading theologians like al-Ghazzâlī may also be read as a testament to their veneration of al-Masīh.

The thesis of the present essay is that the degree to which Muslim theologians are at all prepared to examine Christian teachings, however critically, depends on a pre-existing hermeneutics. Basically, this entails that their attitude towards Christianity, and any other religion for that matter, is determined 
by the kind of scriptural exegesis used in their own schools of thought. The more sophisticated the hermeneutical approach applied to Islamic scripture, the more likely it is that non-Islamic scripture will also be subjected to exegetical scrutiny (rather than rejected or belittled from the outset because it contradicts certain Qurānic narratives). Within this context, the key terms to be explored are 'word' (lafza), 'meaning' (ma'nā), and 'intention' (niyya).

The first part of my paper examines Ibn Hazm (d. ca. 418/1027), who is frequently depicted as a literalist. The following discussion will shed light on the background against which he developed his (so-called) literalism. Rather than summarize his merciless critique of Christianity, as expounded in his Kitāb al-Fișal fi al-Milal wa al-Ahwä' wa al-Nihal (The Separator [Concerning] Religions, Heresies, and Sects), ${ }^{4}$ I will introduce his al-Risāla al-Bähira (The Magnificent Epistle) to uncover the 'authority-centered' epistemological basis of his theology, according to which Truth may solely be found in scripture. Furthermore, I will show the link between this epistemology and Ibn Hazm's linguistic theory, in which words rule over meanings. ${ }^{5}$ The second part of this essay focuses on the prominent Persian philosopher, theologian, and Sufi, al-Ghazzālì (d. 505/1111), whose 'subject-centered' epistemology, in which the seeker is required to validate Truth, permitted him to be inclusive and search for truth in all traditions, sacred or secular, without being limited by wording. This epistemology, moreover, opened the path to a hermeneutical receptiveness that remains unmatched in the Islamic world to this day.

\section{A Ibn Hazm, a Literalist or an 'Apparentist'? The Dominance of Words over Meanings}

Ibn Hazm was an Andalusian logician, theologian, moralist, and littérateur who belonged to the Zāhiri madhhab (=school of law), a school inspired by Dāwūd ibn Khalaf (d. 883), also known as al-Ẓāhirī. The name al-Ẓāhirī is derived from the Arabic word ' $z \bar{a} h i r$ ' (=apparent), as opposed to 'bātin'

4 An excellent discussion of this polemics may be found in Theodore Pulcini, Exegesis as Polemical Discourse. Ibn Hazm on Jewish and Christian Scriptures (Atlanta, Georgia: Scholars Press, 1998). See also Roger Arnaldez, "Controverses théologiques." For more literature see section on Ibn Hazm in David Thomas and Alex Mallett, eds., Christian-Muslim Relations. A Bibliographical History, vol. 3 (Leiden-Boston: Brill, 2011), 137-145.

5 Ibn Ḥazm, al-Risālah al-Bāhirah (The Magnificent Epistle), trans. Muhammad Saghir Hasan al-Ma'sumi (Kuala Lumpur: ISTAC, 1996). This is a different approach from Roger Arnaldez, who takes Ibn Hazm's Tawq al-Hamāma (The Ring of the Dove) to be the key to his thought. See his Grammaire et théorie chez Ibn Hazm de Cordoue. Essai sur la structure et les conditions de la pensée musulmane (Paris: J. Vrin, 1956, 21-23). 
(=hidden, concealed), and is taken to be synonymous with 'literal.' Zāhir and bāțin are paired in Qur'ānic exegesis to allow for (some) scriptural passages to have both an 'apparent' and a 'hidden' meaning, the latter term reflecting what al-Ghazzālī believed to be access to divine 'inner speech,' thus making the text of revelation the expression of God's outer (historic) word. ${ }^{6}$

In our context, the specific (and often overlooked) interest of the Zāhirī madhhab is that it introduced a third approach into the aforementioned dichotomy by differentiating between 'literal' and 'apparent. ${ }^{7}$ To give a concrete example, the frequent Qur'anic reference to the 'Throne of God' may then be read not only metaphorically or literally, but also according to its 'apparent' meaning. Ibn Masarra (d. 319/931), an earlier Andalusian philosopher and Sufi master, took the 'Throne of God' to be a scriptural metaphor for prime matter, thereby suggesting that the act of creation takes effect from where God governs the totality of Being. ${ }^{8}$ By contrast, the literal meaning conjures up the image of the Creator actually sitting, which would imply that God has a corporeal nature. For obvious reasons, literalists have often been attacked by rationalists in Islam, and vice versa. Yet, there is no good reason to think that the apparent meaning should be synonymous with the literal. In fact, this would betray the spirit of Zāhirite teaching that was all bent on fighting anthropomorphisms. To put it succinctly, a Zāhirī is not (necessarily) a literalist, but rather a scholar who rejects the need for a hidden meaning. The middle course therefore consists in focusing on what seems to be the obvious meaning, for instance, understanding that 'Throne' is merely a term used to underline divine majesty. Zāhirites thus succeed in avoiding the trap of an absurd literal reading or of having to assume the existence of a hidden meaning accessible to only few, such as the philosophers and the mystics. Moreover, the method allows the apparent meaning to be either a straightforward or a metaphorical expression. Basically, the school maintains that any Qurānic word or expression has but one meaning in the sentence in which it appears.

6 See Ebrahim Moosa, Ghazālī \& the Poetics of Imagination (Chapel Hill-London: The University of North Carolina Press, 2005), 148-153.

7 Ironically, after having been extinct for many centuries, the Zāhirī School is currently enjoying a comeback in the ultra-conservative Salafiyya scene, where it is being applied rather superficially in defense of a literalist reading of scripture.

8 Miguel Cruz Hernández, "Islamic Thought in the Iberian Peninsula," in The Legacy of Muslim Spain, ed. Salma Khadra Jayyusi (Leiden: Brill, 1992) $777-803$, at 778 . This is precisely the kind of reading denounced later by Ibn Taymiyya (d. 728/1328). In his view, Muslim philosophers who apply their Greek derived knowledge to Qurānic narratives are guilty of corrupting Islamic scripture, both by tabdīl and tahrîf. (See Thomas F. Michel, S.J., ed. and trans., A Muslim Theologian's Response to Christianity. Ibn Taymiyya's Al-Jawab al-Sahih (Delmar, N.Y.: Caravan Books, 1984, 21). 
A good example of eliciting the apparent (as opposed to the literal) meaning of a scriptural passage is when Ibn Hazm underlines that religious injunctions found in scripture apply to both men and women, even when the grammatical expression suggests male addressees only. Following Roger Arnaldez, A. G. Chejne sees Ibn Hazm make use of 'linguistic intuition' in this example, a basic technique consisting of mastering vocabulary, identifying the value of a word within a sentence, and determining the meaning of a word by placing it into the larger textual context. ${ }^{9}$ On a more profound level, Ibn Hazm's exegetical approach relies on his theory of languages as systems of meaning in which every word has an assigned meaning in a given context. Furthermore, the guarantor of univocality in language is God himself:

Any rational being knows that God... arranged languages and provided them with clarity. They consist of expressions resting on clear meanings of designated things. The Almighty God said: "We have not sent any messenger except with the tongue of his people so that he may make things clear to them." The tongue is the language, and there is no disagreement about that. But if speech did not clarify meaning, what things do the deserters of God and His Prophet understand, or with what do they understand each other? ${ }^{10}$

The particular interest of the above quotation is that Ibn Hazm manages to illustrate precisely his approach by pointing out that the apparent meaning of 'tongue' in the Qur'ānic passage cited (Q XIV, 4) does not refer to the muscular organ in one's mouth but to language.' While all languages are able to convey univocal content, the epitome of linguistic clarity is exemplified in scriptural (but not in literary or spoken) Arabic. According to Zāhirī teaching, the Qur’ān not only restores the original revelation once imparted to humankind's first prophets, but it also presents God's words in unambiguous Arabic, as it were, in its primordial purity.11 This explains why, unlike other Muslim theologians, Ibn Hazm did not think that the Bedouins' knowledge of Arabic, however pristine, could be trusted in elucidating scriptural language. Nor was he interested

9 A. G. Chejne, Ibn Hazm (Chicago: Kazi Publications, 1982), 116.

10 Ibid., 120, my emphasis.

11 Roger Arnaldez, Grammaire et théorie, 44-45. On the already existing difference between jurisprudential truth (haqiqa shariyya) and linguistic truth (haqiqa lughawiyya) in Islamic theology, see Ignaz Goldziher, Die Zähiriten. Ihr Lehrsystem und ihre Geschichte. Ein Beitrag zur Geschichte der muhammedanischen Theologie (Leipzig, 1884; repr. Hildesheim: Olms, 1967), 128. 
in tracing the common trilateral roots of scriptural terms in order to elicit their meaning, which represented another common technique borrowed from the Grammarians. Also, Qurānic terms were not to be categorized by genera and species as in Greek logic, but by their meanings, which consequently prompts the question as to how 'meaning' is then to be uncovered.

As Roger Arnaldez has been able to show, Ibn Ḥazm distinguishes between a primary (murād) and a secondary (maqsūd) purport of words (alfāz, pl. of lafza). While the Andalusian recognizes that authors may coin a term by introducing a secondary purport, his focus lies on the primary purport, which is essentially the sense $\left(m a^{\prime} n \bar{a}\right)$ of a word, determined not by an idea or an image but by the word itself and its 'meaning-carrying' intention ('intention significative,' niyya). Basically, Ibn Hazm excludes both the extraneous meaning and the psychological intention that language users introduce in their private vocabulary. ${ }^{12}$ Words are therefore not guided by thought; rather, they determine meanings. Accordingly, truth is not external to the meaning God placed in words.

This extreme nominalism, anchored in the notion that God clarified meaning through the very wording of his revelation, also explains the Zāhirī rejection of qiyās (analogical reasoning) as introduced by Abū Ḥanīfa (d. 150/767), the founder of the Hanafi madhhab, Islam's first and most progressive school of law. Zāhirītes only consider the Qur'ān, Hadìth, and the ïmmác (consensus) of Muhammad's immediate Companions as legitimate sources of law. All other sources are considered bid'a (prohibited innovation). In his Risāla al-Bāhira (The Magnificent Epistle) Ibn Hazm even underlines that the Companions who joined the Prophet on his escape from Mecca to Medina take precedence over later contemporary followers. ${ }^{13}$ And yet, how is one to demonstrate that these are truly the exemplars of knowledge in Islam? Or, put differently, how does one show the futility of the question that asks who among the founders of Islam's (Sunni) schools of law "is grander (ajall), more excellent (afdal), more pious $(a w r a)$, more versed in jurisprudence (afqah), and more knowledgeable

\footnotetext{
12 Ibid., 57.

13 Ibn Ḥazm, al-Risālah al-Bāhirah, 41. The Companions mentioned by name are 'Umar ibn al-Khațāa (Islam's third Khalīf), the Mother of the Believers 'Ā'isha (the Prophet's favorite wife), 'Alī ibn Abī Tālib (Islam's fourth Khalīf), 'Abd Allāh ibn Mas'ūd, and 'Abd Allāh ibn 'Abbās (a cousin of the Prophet). One cannot help but notice the prominent position given to 'A'isha. She is on par with the other Companions in respect to "excellence in knowledge, sagacity, grace, and piety" (ibid.).
} 
(alam)?"14 To opponents raising this question, Ibn Hazm replies sharply that they are obviously unable to judge the words (alfäz) used in their own phrasing:

You are ignorant of their meaning ( $\left.m a^{\prime} n \bar{a}\right)$, you do not master their subject $(m a w d \bar{u})$, you do not understand their truth (haqiqa), you do not know their purport (murād bihi), and you do not comprehend their [philological] exegesis $($ tafsir $) .{ }^{15}$

This brief quotation from the beginning of the Risāla al-Bähira contains nothing less than Ibn Hazm's methodology. What then follows it in the Risäla is an exercise showing how to extract the meaning of words in order to assess their juridical applicability. To mention but one semantic analysis, the Andalusian specifies that the Arabic word 'jalāla' (majesty, same root as ajall, the word translated above as 'grander') refers either to one's rank in society or to one's rank among the believers. Since the first meaning would make no sense in the interrogative sentence cited earlier, while the second one remains necessarily unknown to human beings, Ibn Hazm concludes that the very wording of his opponents' question is inadequate. ${ }^{16}$

It is, therefore, absurd to ask who ... is more learned—Mālik, Abū Ḥanīfa, Shāfììi, Aḥmad or Dāwūd. This question carries no sense, no significance, and is just to care for something useless. No reasonable person will intrigue in a case like this. ${ }^{17}$

Ultimately, the question carries no sense because true knowledge ('ilm) - as needed for legal injunctions - may never be derived. Only the wording found in statements collected directly from a select group of Muhammad's Companions qualifies as such a basis. Therefore, derived knowledge such as in

14 For the original Arabic, see ibid., 100. I have used my own translation, since al-Ma'sumi's rendering of the key words in this passage (ibid., 38) is not consistent with the rendering of the same words later in the text.

15 For the original Arabic, see ibid., 101. Al-Ma'sumi shortens this passage in his rendering (ibid., 38) and seems to be unaware of the importance of the technical terms in it, which is why I offer my own translation. Ibn Ḥazm allows for tafsīr but not ta’wīl (allegorical exegesis).

16 Ibid., $65^{-67 .}$

17 Ibid., 40. The names refer to founders of Sunni schools of law: Mālik ibn Anas (d. 179/795), Abū Ḥanīfa, al-Shāfīìi (d. 205/820), Ahmad ibn Ḥanbal (d. 241/855), and Dāwūd ibn Khalaf al-Ẓāhirī. 
the outcome of analogical reasoning, which necessarily departs from scriptural wording, is a mere opinion and consequently without authority. As a result, even the views expressed by the venerable founders of Islam's schools of law, including Dāwūd, are not legally binding. ${ }^{18}$

The Magnificent Epistle exemplifies what I meant by Ibn Hazm's 'authoritycentered' epistemology in the beginning of the present essay, the 'authority' being the scriptural content as reflected in the concise wording of divine revelation. This is the epistemology that also determines the hermeneutics used by the Andalusian theologian, as well as the background without which one could not possibly situate Ibn Ḥazm's most polemical work, Kitāb al-Fișal, a treatise examining other world religions, in particular Judaism and Christianity. Here, his condemnation of Christian beliefs belongs to the harshest statements one may find in Islam, surpassing in sharpness even the accusations of Ibn Taymiyya.

Theodore Pulcini provides the following list of epithets used by Ibn Hazm in reference to Christians: stupid, irrational, frivolous, impious, lying, obstinate, blindly submissive to authority, arbitrary on belief and practice, avaricious, inferior, and theologically extremist. ${ }^{19}$ Except for 'avaricious,' which the Andalusian uses in reference to Church leaders whose greed he (rightly) accuses, all other epithets suggest that Ibn Hazm is questioning the orthodoxy and orthopraxy of Christians in the same way he would when scrutinizing Muslims following schools of thought different from his own. A typical example for what he takes to be the Christian lack of 'rationality' (logic) may be found where Ibn Hazm is baffled that Christ should be seated at the right hand of God the Father and also be God himself,, ${ }^{20}$ or similarly, that the Father is the Son and the Son is the Father, making a relative relationship turn into a reciprocal one. ${ }^{21}$ Furthermore, the Andalusian also detects numerous contradictions among the Gospel passages, which he imputes to the lack of an abrogative

18 In fields other than theology, Ibn Hazm's position is remarkably different. In his Categories of the Sciences (Marätib al-'Ulüm) he thus underlines: "For the one who speaks on his own authority and on the basis of what he thinks is not the same as the one who speaks on the authority of someone else. A bereaved mother is not the same as a hired mourner. And he who listens to one scholar only will get almost nothing; he would be like the one who persists drinking from one well containing turbid salt, having abandoned sweet and fresh water were he to drink from other wells. Engaging one's equal and opposing enemies in debates that truth can be discerned from falsehood. There is no other way" (A. G. Chejne, Ibn Hazm, 203).

19 Pulcini, Exegesis as Polemical Discourse, 164.

20 Roger Arnaldez, "Controverses théologiques," 221.

21 Ibid., 220. 
methodology (naskh) in Christian theology. ${ }^{22}$ Finally, he also points out the absence of a sound chain of transmission to help create scholarly consensus $\left(i j m \bar{a}^{c}\right) \cdot{ }^{23}$

The greatest difficulty Ibn Ḥazm faces when approaching Christian scripture has to do with metaphors, parables, and other didactic means used in the Gospels. As Pulcini explains:

For example, according to the Christian scriptures, Christ specifically told his disciples that anyone who becomes angry with his brother is liable to judgment and that anyone who sins with his right eye should pluck it out (cf. Mt. 5:22,29). These, Ibn Hazm contends, are clear legal prescriptions from Christ, yet Christians feel no obligation to comply; in failing to obey, they contradict Christ himself. ${ }^{24}$

Whereas Christians read the referenced passages as hyperboles, Ibn Hazm takes them to be religious injunctions with legal force. Essentially, he responds to the quoted Gospel lines in the same way as he would to a verse from Islamic scripture. From where he stands, Christians (who do not make use of the same methodology) are therefore necessarily stupid, irrational, impious, lying, obstinate, arbitrary on belief and practice, inferior, and theologically extremist. Evidently, St. Paul's emphasis on the Spirit of the Law (as opposed to the Letter of the Law, 2 Cor. 3:6) was alien to Ibn Hazm's world of thought.

To answer the question posed in the title of this section, Ibn Hazm can therefore be seen as both an 'apparentist' and a literalist. In respect to his own scriptural tradition, his exegetical goal is to extract the apparent meaning. However, when he applies himself to non-Islamic scriptures such as the Gospels, Ibn Ḥazm takes all non-straightforward expressions à la lettre. In his defense, one may say that since he had to rely on Arabic translations of the Gospels (he mostly focuses on St. Matthew's account) ${ }^{25}$ and had no knowledge of any of the languages relevant to biblical studies (Hebrew, Aramaic, Greek, and Latin), he was in no position to make use of linguistic intuition. It is more

22 Ibid., 226. The Qur'ān is a self-referential text that comments on earlier revealed verses. Naskh is the Islamic exegetical principle that determines which Qurānic verses may be invoked to abrogate, i.e., modify, other verses. For instance, a general principle may require modification in response to historic circumstances.

23 Ibid., 234.

24 Pulcini, Exegesis as Polemical Discourse, 135.

25 For the translation Ibn Ḥazm most likely used, see Pulcini, Exegesis as Polemical Discourse, $185^{-187}$. 
than likely, however, that if Ibn Hazm had been able to read the original Gospels, he would still have insisted on interpreting any imperative phrasing as a divine command ( $a m r)$.

\section{B Al-Ghazzālī: Journeying beyond Words to Reach Meanings}

A very different tone emerges from al-Ghazzâlī's writings, which is not to say that the Persian philosopher could not be a polemicist as well. It suffices to mention his harsh invective against the Bāținites, as the Ismāîlīs were called in his native region, or his Tahäfut al-Falāsifa (Incoherence of the Philosophers), in which he brilliantly argues against twenty theses he singled out from the works of the Peripatetic philosophers al-Fārābī and Ibn Sīnā because they challenged or contradicted orthodox Islamic teaching. On the whole, however, al-Ghazzāli appropriates, adapts, and integrates non-mainstream Islamic as well as nonIslamic sources whenever he recognizes the intrinsic value of their teaching, be it a concept, a single statement, or a metaphor. This is in keeping with the strict criteria for certainty formulated in his al-Munqidh min al-paläl (The Deliverance from Error), the autobiography he wrote upon returning home from years of wanderings as a humble Sufi. ${ }^{26}$

In terms of ancient sources, al-Ghazzālī seems to have had a predilection for authors from the Roman period. Thus, without mentioning the name of the Stoic philosopher Epictetus, he expands the latter's sea voyage metaphor in which passengers disembark on an island with some interrupting the journey all together, the island being a metaphor for the trappings of earthly existence. At other times he describes himself as a diver for truth, tacitly borrowing the metaphor from Diogenes Laertius (who attributed it to Socrates). ${ }^{27}$ Naturally, al-Ghazzālī also makes frequent references to themes, terms, and teachings derived from pre-Islamic Persia, such as the Zoroastrian metaphysics of light. As if he had anticipated the attacks of the later Ibn Taymiyya for having dared to quote the verses of a Christian Arab poet in support of there being an 'inner speech' of God, al-Ghazzālī took great efforts to clarify his approach to truth in

26 Al-Ghazali, Deliverance from Error. Five Key Texts Including His Spiritual Autobiography al-Munqidh min al-Daläl, trans. and annot., Richard Joseph McCarthy (Louisville: Fons Vitae, 2004), 57 .

27 Cf. Tamara Albertini, "Mystical Landscapes-Places of the Mind. Emptiness and Plenitude in Islamic Philosophy," in Labirinti della mente. Visioni del mondo. Il lascito intellettuale di Elémire Zolla nel XXI secolo, ed. Grazia Marchianò (Siena: Società Bibliografica Toscana, 2012) 175-190, at 184, 185 . 
The Deliverance from Error: knowledge is not to be defined by identity. ${ }^{28}$ In other words, the provenance of a statement or an insight may not influence either its acceptance or rejection. In the same way as a well-trained magistrate listens to all voiced opinions without adopting any before due scrutiny, the philosopher too is under the obligation to remain impartial when searching for truth in different traditions. To support this, the Persian philosopher cites a famous saying: "Do not know the truth by men, but rather know the truth and you will know its adherents." ${ }^{29}$ The statement is quite poignant, also for the fact that it happens to be a quotation of 'Alī ibn Abī Țālib, Islam's fourth Khalīf and the revered first Imam of the Shī'a. Al-Ghazzāli goes one step further in his uncompromising and impartial embrace of truthfulness, claiming that it is to be acknowledged even where it is mingled with obvious falsehood or errors. Regarding the Ikhwān al-Ṣafā (The Brethren of Purity), another group of Shī'ites for whom he had little sympathy, he thus writes: "If we were... to aim at forgoing every truth which had been first formulated by the mind of one in error, we would have to forgo much of what is true." ${ }^{30}$ What al-Ghazzāli meant to express is that, although he had many issues with the teaching of the Ikhwān, he still gave them credit for citing or deriving truthful statements from scripture, Sufi teachings, and other authoritative sources. Not surprisingly, the Persian philosopher therefore had no difficulty in both accepting and rejecting the statement of a Christian affirming "there is no God but God; Jesus is the apostle of God," i.e., recognizing the validity of the monotheistic creed but objecting to Jesus (rather than Muhammad) being the Apostle of God.

Hence, if he [the Christian] is an unbeliever only because of his denial of the latter [Muhammad's prophethood], he should not be contradicted in matters other than what he disbelieves. I mean something which is true in itself, although the Christian also holds to be true. ${ }^{31}$

Put in a different way, if one were to reject the entire Christian creed, this would also apply to its true portion, i.e., the assertion that God is one. It is tempting to think that al-Ghazzālī had a favorable bias towards Christianity, certainly more favorable than towards the Shi'a. However, this is not the same as having any particular leaning for Christian teaching. Instead, as the following will show, it was al-Ghazzālì's 'Islamized' understanding of Jesus that facilitated a benign attitude towards Christianity.

\footnotetext{
28 Ebrahim Moosa, Ghazālī \& the Poetics of Imagination, 148-153.

29 Al-Ghazali, Deliverance from Error, 68.

$30 \quad$ Ibid., 69 .

31 Ibid., 68, my emphasis.
} 
To return to al-Ghazzālì's notion of knowledge, a precondition for the one who earnestly desires to find truth in any tradition is to uncover the meaning (ma'na $)$ of a teaching, statement, or injunction. In tune with his ethics, in which the intention (niyya), not the outcome of an act, serves as the measure of one's deeds, the Persian philosopher analyzes Christian Trinitarian teaching in light of what it is designed to convey. Here is his analysis from one of his epistles:

When Christians refer to God as the third of the three, they do not mean that God is [numerically] three... indeed God is one in his essence [dhāt] and three with respect to his attributes [șifât]. And this is the wording of their statement: One in substance [jawhar] and three by way of hypostasis [uqnümiyya]. By 'hypostasis,' they mean attributes. ${ }^{32}$

Al-Ghazzālī is remarkably accurate in rendering the early Christian Trinitarian understanding; some of his wording sounds like a gloss or may possibly be a direct quotation of a Christian source. ${ }^{33}$ Notably, he explores the creed without condemning it beforehand or 'correcting' the message it conveys. He focuses instead on what 'they mean' to express, not what the creed says verbatim. In stark contrast to Ibn Hazm, al-Ghazzāli thinks wording is secondary to intention. For him, the hermeneutical challenge consists in discovering the psychological intention of the author (human or divine), rather than the intention attached to the meaning that the words themselves carry.

Regarding his fellow theologians (mutakallimūn), it is not surprising that al-Ghazzâlī says that they ably defended orthodoxy but utterly failed in arriving at primary and self-evident truths:

They relied on premises which they took over from their adversaries, being compelled to admit them either by uncritical acceptance, or because of the Community's consensus, or by simple acceptance derived from the Qur'ān and the Traditions. ${ }^{34}$

32 Ebrahim Moosa, Ghazālè \& the Poetics of Imagination, 149, my emphasis. In this statement al-Ghazzâli tacitly applies the two categories of divine names in Islam: those that refer to God's essence, and names that are divine attributes.

33 Roger Arnaldez makes reference to an earlier researcher who showed that al-Ghazzāli had consulted a Coptic version of St. John's Gospel during his stay in Egypt. See his "Controverses théologiques," 245-246.

Al-Ghazali, Deliverance from Error, 59 . 
Scripture is considered a source of knowledge, but not knowledge itself. Its truth only makes itself manifest to the one who validates knowledge, either by the use of (critical) credence in other people's testimony (immann), apodeictic proofs, or mystical fruition (dhawq) - basically, by one of the three degrees of knowledge with which the seeker may gain certainty of the veracity of a teaching. ${ }^{35}$

Al-Ghazzālī's 'subject-centered' epistemology accords with the hermeneutical recommendation he issued in his magnum opus, the Ihya a Ulüm al-Din (The Revival of Religious Sciences):

If you examine the writings of anyone who had gained distinction in knowledge, then do not so with condescension... And do not stop where the author's text ends. For, surely, meanings are more expansive than their literal expressions, and the bosoms [hearts] are more capacious than compiled books, for there is much knowledge in what is not articulated. So aspire to grasp all the possible meanings of his writing with the perception of his heart. ${ }^{36}$

There could not be a clearer invitation to explore a text beyond its mere verbal expression. A very different approach, however, may be found in his al-Durra al-Fäkhira (The Precious Pearl), a short eschatological treatise that the Persian philosopher wrote for a wider audience. In it he envisages God summoning Jesus son of Mary on the Day of Judgment to 'recite' the Gospel. Jesus complies and "he brings the Gospel fresh and new, so that even monks think that they have never known one verse of it."37 While al-Ghazzālī remains faithful to the Islamic position that takes the historic Gospel text to be a corrupted version of a pre-existing original, he is careful not to state what the differences between the two versions might be. Instead, he has Jesus most delicately make one single 'correction.' This approach is quite different from Ibn Hazm and Ibn Taymiyya, the latter of whom had once bluntly declared: "And the Christians have erred in the denotation [musammā] of speech [kalām], so they made the messiah [Jesus] self-sufficient, who is then identical to the word of God." ${ }^{38}$

35 Ibid., 82.

36 Ebrahim Moosa, Ghazālı̀ \& the Poetics of Imagination, 114.

37 Jane Idleman Smith, The Precious Pearl. A Translation from the Arabic with Notes of the Kitāb al-Durra al-Fākhira fì Kashf Ulūm al-Ākhira of Abū Hāmid Muhammad b. Muḥammad b. Muḥammad al-Ghazālī (Harvard University: Scholars Press, 1979), 67. 
Obviously, The Precious Pearl does not include the 'original' Gospel. The only change it reflects is the one applied to the notion of Holy Trinity. Thus, before God instructs Jesus to recite the Gospel he asks him: "Did you say to people 'Take me and my mother as gods, apart from God?'” To this Jesus responds:

It is not for me to say what I have no right to say. Had I said it, You would have known it. You know what is in my soul, though I do not know what is in Yours. ${ }^{39}$

Al-Ghazzālì's reaction to Christian Trinitarian teaching in The Precious Pearl is noticeably different from the one expressed in his epistle. In the eschatological treatise composed for the non-specialist, no attempt is made to assess the possible compatibility between Christian and Islamic teachings. Like all welltrained Muslim theologians, al-Ghazzālī is careful not to confuse or put doubt in the mind of believers, who may be insufficiently trained or lack intellectual aptitude to discuss the 'inner meaning' of a scriptural text, either Islamic or Christian for that matter. Remarkably, though, Jesus does not explicitly reject the notion of Holy Trinity in The Precious Pearl. All he does is clarify that he never meant that he and his mother should be divinized. In other words, the Persian philosopher has Jesus only address the vulgarized version of Holy Trinity, which mentions Mary as the third divine person instead of the Holy Spirit. Another point of interest is Jesus's Islamized features. For instance, he is called upon to recite the Gospel the way Muslims ritually chant the Qur'àn from memory. Also, Jesus (who leads the poor on the Day of Judgment) is lauded for his poverty, not for his love, charity, or compassion.

Learn a lesson from the messiah, for it said that he had no purse at all, that he was dressed in the same woolen garment for twenty years, and that in his travels he had only a small mug and a comb. One day he saw a man drinking with his hand, so he threw the mug from his hand and never used it again. Then he passed by a man running his fingers through his beard, so he threw away the comb from his hand and never used it after that. ${ }^{40}$

39 Smith, The Precious Pearl, 67. This is a direct scriptural quotation (Q V, 116).

$40 \quad$ Ibid., 77. 
In al-Ghazzālī's version, when Jesus encounters individuals poorer than he is, he does not offer them his few possessions. Instead, the mug and comb are merely tossed away. Jesus thus comes across as the embodiment of Islamic asceticism from the period preceding the rise of Sufism, i.e., Islamic mysticism, of which al-Ghazzālī stated that its greatest achievement was its injection of love into Islamic spirituality. Therefore, it may not be a coincidence that only two pages after the above quotation, the Persian philosopher cites the famous Muslim ascetic Hasan al-Bașrī, who lived precisely at the time when Islamic asceticism transformed into a mystical movement. From a Christian point of view, one might say that Jesus's poverty was the expression of his love for humankind and that love is therefore the dominant element in Christ's teaching. However, one should also bear in mind that asceticism was a particularly salient feature of Eastern Christianity, which would explain al-Ghazzāli's great emphasis of Jesus's own ascetic lifestyle in the Precious Pearl. Christ's love (of God), however, is greatly alluded to in another work of al-Ghazzālì's.

In Love, Longing Intimacy and Contentment (Kitāb al-Mahabba wa al-Shawq wa al-Uns wa al-Rida $)$, another book of the Ihy $\bar{a}^{3}$ and with a strong emphasis on Sufism, al-Ghazzālī speaks of Jesus as one of God's preferred prophets. He explains the matter by stating: "it was based on the graciousness he [Jesus] had witnessed in the stage of intimacy." ${ }^{41}$ 'Intimacy' is translated from 'uns,' a technical term of Islamic mysticism that al-Ghazzāli interprets as the exultation of the heart that experiences closeness to God. ${ }^{42}$ The language used in Love, Longing Intimacy and Contentment clearly indicates that Christ is taken to be a mystic. Moreover, Jesus's preference for the longing for heaven over the fear of hell, and for the love of God over the desire for heaven, ${ }^{43}$ is reminiscent of a saying attributed to Rābi'a al-'Adawiyya (d. 185/801), one of Islam's earliest mystics, whose loving memory the Persian philosopher helped preserve:

I am going to light a fire in Paradise and to pour water on to Hell, so that both veils (i.e., hindrances to the vision of God Himself) may vanish altogether from before the pilgrims and their purpose may be sure, and

41 Al-Ghazālī, Love, Longing Intimacy and Contentment. Kitāb al-mahabba wa al-shawq wa al-uns wa al-rid̄ā, Book XXXVI of the Revival of the Religious Sciences Ihyä' 'ulüm al-dīn. Translated with an Introduction \& Notes by Eric Ormsby (Cambridge: The Islamic Texts Society, 2011), 142, my emphasis.

42 Ibid., 133. More passages mention the Sufi heart (qalb) in relation to Jesus; see 159, 185, and 190.

Ibid., 37 . 
the servants of God may see Him, without any object of hope or motive of fear. ${ }^{44}$

Unlike Ibn Hazm, who squarely opposed the Christian notion of Jesus's divinity, al-Ghazzāli teases out a 'meaning' that keeps the communication lines open between Islam and Christianity. Jesus the Sufi is a judicious solution allowing for an allusion to the 'divinity' of Christ in terms that are agreeable if not to all Muslims, at least to those receptive to mysticism. However, an oblique comment inserted in Love, Longing Intimacy and Contentment in reference to a statement made by the crucified Muslim mystic al-Hallāj (d. 309/922) clarifies that the Persian philosopher was not prepared to go as far as to accept the concept of incarnation..$^{45}$ For al-Ghazzālī, Jesus was the intimate of God whose Self was possibly annihilated or absorbed into God. He may even grant Jesus that he experienced the "exchange of attributes" (tabaddul al-sifa $\bar{t}$ ), ${ }^{46}$ a mystical transformation al-Ghazzālī speaks of in his autobiography and that entails the surrender of one's human nature to God without entering into a full-scale union with the Creator. While this interpretation may not satisfy Christians, it nevertheless remains the expression of a Muslim scholar anxious to root Christianity in a religious experience common to both Christians and Muslims. Al-Ghazzālī achieved this by taking the subjective experience of a Sufi filled with the presence of God as an explanation for the Christian notion of Jesus's divinity. His approach exemplifies superbly that understanding each other across different religions and cultures does not begin by fighting over words, but by attempting to agree over meanings.

44 Margaret Smith, The Way of the Mystics. The Early Christian Mystics and the Rise of the Süfis (New York: Oxford University Press, 1978), 187-188.

45 Al-Ghazālī, Love, Longing Intimacy and Contentment, 39-40. This is a view one finds expressed also in Al-Radd al-Jamill lī-Ilāhiyya 'Tsà bi-Sarīh al-Injül (The Fitting Refutation of the Divinity of Jesus Through What Is Evident in the Gospel), a short treatise that some scholars take to be an authentic work by al-Ghazzālī (for more details see section on al-Ghazzālī in Thomas and Mallett, Christian-Muslim Relations, vol. 3, 367-369). The style, syntax, and vocabulary used in Al-Radd al-Jamïl are very different from al-Ghazzālī's writing in his other theological works. I, therefore, see no basis to confirm his authorship. Besides, since al-Ghazzālī's interpretation of Jesus as a Sufi master is sufficiently evident in the Ihyä'Ulüm al-Dìn, the present essay has no need of Al-Radd al-Jamill to make that case.

Al-Ghazali, Deliverance from Error, 78 . 
One may never establish with certainty whether al-Ghazzālī single-handedly cut the stones needed to build a bridge between Christianity and Islam, or whether he adapted pre-existing, possibly non-mainstream, Christological notions to his interpretation of Jesus the Sufi. What matters in the end is that the Persian philosopher successfully crossed that bridge, and that many more may also endeavor the passage—in both directions. 